\title{
A transnational judicial public sphere as an idea and ideology: Critical reflections on judicial dialogue and its legitimizing potential
}

\author{
K N U T T R A I S B A C H \\ University of Barcelona, Diagonal 684 and University Ramon Llull, ESADE, Av. Pedralbes 60-62, 08034 \\ Barcelona, Spain
}

Email: traisbach@ub.edu

\begin{abstract}
This article sheds a critical light on judicial dialogue when its purpose and meaning are taken beyond cross-fertilization and comparative reasoning. It cautions against a conceptualization of judicial dialogue as a means to foster commonalities between courts and to legitimize judicial governance. The argument develops from an idealized notion of a 'transnational judicial public sphere'. In this sphere, domestic, regional and international courts ideally form common opinions through dialogue and pursue common purposes. The danger of this understanding is to construct a new paradigm that not only overlooks important differences in the interest, influence and opinion of courts, but also overstates the socio-normative significance of exchanges between courts and of judicial governance in general. The critical potential of judicial dialogues lies less in the formation of commonalities or in the legitimization of judicial authority than in bringing alternatives and a plurality of opinions to the fore.
\end{abstract}

Keywords: governance; judicial dialogue; judicial authority; legitimacy; transnational public sphere

\section{Introduction}

Dialogue is everywhere. We hear about the need for dialogue between politicians, civilizations, religions, cultures, institutions or, in the international normative context, between legal orders and their actors. Dialogue has positive connotations, whereas the absence of dialogue implies a standstill, clash, divide, ignorance or fragmentation. Dialogue is usually seen as a necessary first step to overcome divides. Actors shall talk and listen to each other, exchange arguments and learn from each other. From a sociopolitical perspective, dialogue is the prime process of bringing actors closer 
together. It is a means of making communities 'imaginable', ${ }^{1}$ and of promoting a move from the mere coexistence of actors to possible cooperation towards the realization of common interests. ${ }^{2}$ It is, therefore, not surprising that in an understanding of the global legal order as a unified system, in which problems of fragmentation need to be 'solved' and gaps in the law need to be 'closed', dialogue between courts is conceived as a possible cure to ensure the coherence and unity of 'the system'. 3

My argument is not that dialogue between judges does not exist, nor that this exchange should be avoided. My aim is to shed a critical light on judicial dialogue when its purpose and meaning are taken beyond cross-fertilization and comparative reasoning. My concern is to caution against an idealization of these inter-judicial exchanges as a means to construct commonalities between courts and ultimately to legitimize judicial governance. I point to structural inequalities and processes of socialization that exist within these allegedly open and rational dialogues. Dialogue is not free of power dynamics and unequal quests for influence. Because of the particular functions and authority of courts, these dynamics become even more subtle and escape effective oversight in a transnational setting.

I rely on the notion of an idealized transnational judicial public sphere, in which national, regional and international courts ideally form common opinions through dialogue and pursue common purposes. Relying on scholarship on the societal public sphere and the critique of its legitimizing potential, I use this notion to describe an idealized discursive sphere in which judges supposedly freely and equally discuss questions of law and society. In this sphere, courts allegedly engage argumentatively with each other in order to find common solutions to common problems, develop the law according to common standards or advance integration into a shared community. They cooperate to protect and promote common interests, the common good and common values. I believe that this notion of an idealized transnational dialogical sphere, together with its connotations, is implicit in many

${ }^{1}$ J Habermas, 'Public Space and Political Public Sphere: The Biographical Roots of Two Motifs in My Thought' in J Habermas (ed), Between Naturalism and Religion (Polity Press, Cambridge, MA, 2008) 11, 15-16.

${ }^{2}$ Much of the international law literature refers in this context to W Friedmann, The Changing Structure of International Law (Stevens \& Sons, London, 1964) as a source for the idea of this 'move' towards cooperation and community interests in international law, often implying that cooperation substituted for coordination. Friedmann, however, argued that new levels of cooperation had developed that existed parallel to the established - and persisting-levels of coordination.

${ }^{3}$ For valuable discussions of different purposes of supranational and national courts beyond adjudication, see the contributions in OK Fauchald and A Nollkaemper (eds), The Practice of International and National Courts and the (De-)Fragmentation of International Law (Hart, Oxford, 2012). 
conceptualizations of judicial governance that presume the existence of a network, alliance or community of courts.

The notion of a transnational judicial public sphere connects my discussion of judicial dialogue with themes of judicial governance, the exercise of public authority by courts, informal normative settings and critical democratic theory. The notion of the public sphere in modern democracies describes a sphere separate from politics, involving - at least in principle - everybody, where citizens through a rational discussion develop a public opinion that is able to exert a normative force on political decision-makers. Although the public opinion is not necessarily the outcome of direct dialogue but stems from dispersed processes, it is nevertheless regarded as the result of a wider process where society comes to a common mind and pursues a common end. ${ }^{4}$ This is the ideal that I identify also in conceptualizations of judicial dialogues.

The qualification of this sphere as 'public' relates to the exercise of public authority by judges, and thus to effective influence on state policy. It also relates to the presumed openness of participation in the debates in this sphere and to the capacity of the debate to structure itself in such a way that a common opinion emerges. ${ }^{5}$ Since judicial dialogue and judicial governance are often discussed in the context of supposedly disaggregated nation states with weakened domestic parliaments and governments, 'public' also refers to the legitimization of this (compensatory) public authority exercised by supranational courts and tribunals.

A small disclaimer is necessary. There are important differences between the transnational dialogical sphere of courts and the public sphere(s) in society. Exchanges between courts cannot have the same quality and effects as deliberations in parliaments or in public spheres in society. Parliaments are strong, institutionalized publics with decisional powers. Discourses in civil society, in turn, are usually informal and not necessarily influential. ${ }^{6}$

\footnotetext{
${ }^{4}$ See, for example, C Taylor, 'Liberal Politics and the Public Sphere' in C Taylor (ed), Philosophical Arguments (Harvard University Press, Cambridge, MA, 1995) 225, 261-64; at 266, he describes the ideal of the public sphere as follows: 'So what the public sphere does is to enable the society to reach a common mind, without the mediation of the political sphere, in a discourse of reason outside power, which nevertheless is normative for power'; see also section III of this article.

${ }^{5}$ Ibid. and C Taylor, 'Invoking Civil Society' in C Taylor (ed), Philosophical Arguments (Harvard University Press, Cambridge, MA, 1995) 204, 208 and 216-17.

${ }^{6}$ For the distinction between strong (decisional) and weak publics, see N Fraser, 'Rethinking the Public Sphere: A Contribution to the Critique of Actually Existing Democracy' in C Calhoun (ed), Habermas and the Public Sphere (MIT Press, Cambridge, MA, 1992) 109, 134-36. For Fraser, weak publics engage in deliberative opinion formation but not in decision-making, whereas strong publics, such as parliaments, engage in opinion formation and binding decision-making. Strong publics often show a large degree of institutionalization and are part of the state structure. This clear distinction is blurred by weak publics that strive to gain more decisional power, by hybrid forms and by the plurality of publics and counter-publics that can be found within 'a' public sphere. A similar differentiation can be found in JL Cohen and A Arato,
} 
Courts are actors with decisional power, and they form part of a formal institutional order. They represent a specific branch in the separation of powers and fulfil a particular adjudicative function in a legal order. ${ }^{7}$ Judicial dialogue might appear as taking place in an informal, even weak transnational judicial public sphere, but at the same time courts are strong, decisional institutions.

Whenever dialogue is - explicitly or implicitly - linked to the idea of a transnational community, network or alliance with alleged common purposes and interests, we need to enhance our sensibilities for the subtle dynamics of homogenization and socialization that permeate these dialogues. Judicial dialogue can easily become a new bias in terms of how observers portray judicial 'cooperation' in post-national constellations. The danger is to construct a new paradigm that not only overlooks important differences in interests, influence and opinion of courts, but also overstates the social significance of exchanges between courts and of judicial governance.

My argument proceeds as follows: In section II, I outline a particular liberal view that portrays interacting courts as proactive actors in transnational governance processes. I then describe in section III wider purposes and effects that are associated with dialoguing and cooperating courts. Section IV stresses inherent conditionalities and systemic obstacles affecting judicial dialogue. I rely here on accounts of the bourgeois public sphere by Jürgen Habermas and others, who critically discuss this idealized sphere of open discourse. In section V, I point to a more critical understanding of the role of judicial dialogues in transnational normative processes. Conclusions are offered in section VI.

\section{Beyond adjudication: The idea of judicial governance in a 'post-Westphalian' world}

The increased number and influence of international courts and tribunals have attracted much attention in scholarship over recent years. Already US

Civil Society and Political Theory (MIT Press, Cambridge, MA, 1992), who differentiate between civil and political publics. Civil publics are relatively unconstrained and informal but may develop into more organized forms to exert direct influence on decision-makers. Political publics are formal publics who produce binding decisions. See also A Arato, 'Procedural Law and Civil Society: Interpreting the Radical Democratic Paradigm' in M Rosenfeld and A Arato (eds), Habermas on Law and Democracy: Critical Exchanges (University of California Press, Berkeley, CA, 1998) 26, 33; J Cohen, 'Trust, Voluntary Association and Workable Democracy: The Contemporary American Discourse of Civil Society' in ME Warren (ed), Democracy and Trust (Cambridge University Press, Cambridge, 1999) 208, 215.

7 On the role of courts and their relation to parliamentary deliberation, see J Waldron, 'The Rule of Law and the Role of Courts' (in this issue); BZ Tamanaha, 'Always Imperfectly Achieved Rule of Law: Comments on Jeremy Waldron' (in this issue). 
legal realists have pointed to the role of courts as proactive agents for the intentional development of domestic legal regimes. ${ }^{8}$ This understanding of courts as not only engaging in adjudication but purposefully acting through adjudication has received further momentum with the establishment of numerous new regional and international legal regimes with judicial and quasi-judicial bodies. $^{9}$ Related to this development is the identification of multiple disaggregation processes of states caused by the transfer of traditional state functions and competences to supranational and transnational actors. Eyal Benvenisti describes these disaggregation processes as follows:

The formal delegation of authority to international institutions and informal intergovernmental coordination render significant parts of the domestic decision-making processes of most countries ineffectual ... But the challenge runs even deeper, for it jeopardizes the very idea of democracy. The ability of citizens to participate in decisions affecting them becomes merely formal, as the domestic political branches fail to withstand the pressure brought to bear by domestic and foreign interest groups and foreign governments. ${ }^{10}$

The globalization of decision-making processes, influenced by multiple public and private actors, is perceived as a jeopardy, and the openness of local democratic legal systems to these forces is seen as a vulnerability. The increase of governance activities by supranational actors and the alleged disaggregation of the state complement each other in these depictions.

Against this background, some scholars analyze courts and judges as agents who actively engage in governance themselves and defend the rule of law against powerful transnational actors that escape effective regulation. Anne-Marie Slaughter has been the most outspoken - and perhaps most controversial - scholar in this regard, offering a far-reaching theory of transnational governance networks. This theory builds on a particular liberal outlook on international society. Building on neo-Kantian presets,

\footnotetext{
${ }^{8}$ For an excellent discussion, see BZ Tamanaha, Beyond the Formalist-Realist Divide: The Role of Politics in Judging (Princeton University Press, Princeton, NJ, 2009).

9 KJ Alter, The New Terrain of International Law: Courts, Politics, Rights (Princeton University Press, Princeton, NJ, 2014); for the neo-functionalist approach to the regional integration in Europe, see A Stone Sweet, Governing with Judges: Constitutional Politics in Europe (Oxford University Press, Oxford, 2000); A Stone Sweet, The Judicial Construction of Europe (Oxford University Press, Oxford, 2004).

${ }^{10}$ E Benvenisti, 'Reclaiming Democracy: The Strategic Uses of Foreign and International Law by National Courts' (2008) 102 American Journal of International Law 241, 245 and 246. See also AM Slaughter, A New World Order (Princeton University Press, Princeton, NJ, 2004) 8-14; S Benhabib, 'Democratic Iterations: The Local, the National, and the Global' in RC Post (ed), Another Cosmopolitanism (Oxford University Press, Oxford, 2008) 45, especially 46-48 regarding citizenship.
} 
Professor Slaughter has developed a model of judicial government networks in the age of globalization in which judges actively engage in dialogue and cooperation across borders. ${ }^{11}$ She argues that these government networks, which include judicial networks, can converge regulations, increase compliance with national and international rules, improve cooperation and address global challenges more effectively. ${ }^{12}$ She conceptualizes judicial interactions as regulatory networks, which together form a global legal system:

[G]overnment networks would not only produce convergence and informed divergence, improve compliance with international rules, and enhance international regulation by information ... [T] hey could do much more to instill and champion norms of honesty, integrity, independence, and responsiveness and to bolster those members who face domestic resistance in enforcing those norms. ${ }^{13}$

Judges participate in what she calls a 'global community of law' and engage in a global legal discourse. ${ }^{14}$ This emerging judicial community is based on a shared legal language and creates a 'transjudicialism' of networked courts. ${ }^{15}$ More importantly, according to the underlying liberal world view, judges are committed to similar liberal values and are able to both empower and control each other in this transnational community of courts. ${ }^{16}$

In this context, judicial dialogue becomes a network-forming link that can protect local political deliberation against external pressures and empower pluralistic democratic processes. ${ }^{17}$ Slaughter's ultimate vision is a new world order where these government networks increasingly address global and transnational problems, which compensate for the disaggregation of the state. She describes this new world order as 'a system of global governance

11 The basic tenets of Anne-Marie Slaughter's theory are contained in AM Slaughter, 'A Typology of Transjudicial Communication' (1994) 29 University of Richmond Law Review 99; AM Slaughter, 'International Law in a World of Liberal States' (1995) 6 European Journal of International Law 503; AM Slaughter, 'The Real New World Order' (1997) 76 Foreign Affairs 183; AM Slaughter, 'A Global Community of Courts' (2003) 44 Harvard International Law Journal 191; AM Slaughter, New World Order (n 10) and AM Slaughter and WW Burke-White, 'The Future of International Law is Domestic (or, the European Way of Law)' (2006) 47 Harvard International Law Journal 327.

12 Slaughter, New World Order (n 10) 166-95.

13 Ibid 195-96.

14 Slaughter, 'Typology' (n 11) 136; LR Helfer and AM Slaughter, 'Toward a Theory of Effective Supranational Adjudication' (1997) 107 Yale Law Journal 273, 366; AM Slaughter, New World Order (n 10) 63-103, 179-82 and 186.

15 Slaughter, 'Typology' (n 11) 69; for the terminology of 'transjudicialism', see M Toufayan, 'Identity, Effectiveness, and Newness in Transjudicialism's Coming of Age' (2009-10) 31 Michigan Journal of International Law 307, 314 et seq.

16 Slaughter, New World Order (n 10) 230-44.

17 Ibid 184 and 213; Benvenisti, 'Reclaiming Democracy' (n 10) 241. 
that institutionalizes cooperation and sufficiently contains conflict so that all nations and their peoples may achieve greater peace and prosperity, improve their stewardship of the earth, and reach minimum standards of human dignity'. ${ }^{18}$

This far-reaching vision of courts and governance networks has been criticized as Eurocentric, as not supported by empirical facts and as a liberal idealization. ${ }^{19}$ I believe, nonetheless, that similar assumptions about the potential, purposes and effects of dialoguing and cooperating courts exist in other analyses of networked courts. ${ }^{20}$ Of course, there are important differences among these analyses, and some criticize an exclusive or exaggerated focus on judicial governance. However, these conceptualizations often assume that courts act purposefully together and cooperate transnationally to pursue purposes that go beyond adjudicating a particular legal case. Courts allegedly pursue these goals not in an isolated manner but within a cooperative network based on dialogue and exchange. In the following section, I restate some of these wider purposes and alleged effects that are ascribed to dialoguing courts.

\section{Wider purposes and meanings of judicial dialogue}

In judicial networks, courts allegedly engage in dialogue not only to enrich their own jurisprudence, but to find common solutions to common problems. ${ }^{21}$ I mentioned already that dialogue between those actors, which can contribute to the fragmentation of the legal order through divergent

18 Slaughter, New World Order (n 10) 15, 166 and 213; see also E Benvenisti and GW Downs, 'National Courts, Domestic Democracy, and the Evolution of International Law' (2009) 20 European Journal of International Law 59, 68 et seq.

19 See, for example, A Mills and T Stephens, 'Challenging the Role of Judges in Slaughter's Liberal Theory of International Law' (2005) 18 Leiden Journal of International Law 1; F Kratochwil, 'How (Il)Liberal is the Liberal Theory of Law? Some Critical Remarks on Slaughter's Approach' (2010) 9 Comparative Sociology 120, 135; A Wiener and P Liste, 'Lost Without Translation? Cross-Referencing and a New Global Community of Courts' (2014) 21 Indiana Journal of Global Legal Studies 263.

${ }^{20}$ See E Benvenisti and GW Downs, 'The Democratizing Effects of Transjudicial Coordination' (2012) 8 Utrecht Law Review 158 and the other contributions in the special issue on highest courts and transnational interaction; see also section III of this article.

${ }^{21}$ See TI Harbo, 'Legal Integration Through Judicial Dialogue' in Fauchald/Nollkaemper (n 3) 167; from the 2012 special issue on highest courts and transnational interaction of the Utrecht Law Review, see M Claes and M de Visser, 'Are You Networked Yet? On Dialogues in European Judicial Networks' (2012) 8 Utrecht Law Review 100; for the relation between 'publicness' and the pursuit of a common interest and the common good, see A v Bogdandy, M Goldmann and I Venzke, 'From Public International to International Public Law: Translating World Public Opinion into International Public Authority' (2017) 28 European Journal of International Law 115, 136-39. 
rulings, will lead to greater formal coherence in the legal order. ${ }^{22}$ It is also posited that judicial dialogue may promote the development of a transnational rule of law, at least in the sense that the judicial protection of the rule of law becomes more functionally interdependent. ${ }^{23}$

Moreover, judicial dialogue shall promote objectives of democracy and global justice. Courts that are embedded in networks and interconnected through dialogue will address global challenges such as human rights violations, inequality or climate change more effectively beyond local institutional and political constraints. According to this view, judicial dialogue creates a discursive 'space insulated from politics' for 'developing a political consensus as to the common good to be pursued by the "community" under the banner of universalism'. ${ }^{24}$

22 See Benvenisti and Downs (n 18) 70; for further discussion, see the contributions in the volume P Lobba and T Mariniello (eds), Judicial Dialogue on Human Rights: The Practice of International Criminal Tribunals (Brill, Leiden, 2017) with a focus on the reception of ECtHR's case law by international criminal tribunals; see also the conclusions in VP Tzevelekos, 'The Use of Article 31(3)(c) of the VCLT in the Case Law of the ECtHR: An Effective Anti-Fragmentation Tool or a Selective Loophole for the Reinforcement of Human Rights Teleology? Between Evolution and Systemic Integration' (2010) 31 Michigan Journal of International Law 621; R Nordeide, 'The ECHR and its Normative Environment: Difficulties Arising from a Regional Human Rights Court's Approach to Systemic Integration' in Fauchald/Nollkaemper (n 3) 118; J D'Aspremont, 'The Systemic Integration of International Law by Domestic Courts: Domestic Judges as Architects of the Consistency of the International Legal Order' in Fauchald/Nollkaemper (n 3) 141, who all, not surprisingly, conclude that 'systemic integration' ultimately depends on the interpretation of the court of what 'the system' requires in the specific case; Y Shany, 'One Law to Rule Them All: Should International Courts Be Viewed as Guardians of Procedural Order and Legal Uniformity?' in Fauchald/Nollkaemper (n 3) 15 warns at 33 that 'the appeal to systemic considerations as the basis of jurisdiction-regulation and norm-coordination measures is unlikely to garner the broad support of international courts in practice, given the institutional incentives to prioritise the expectations of other stakeholders such as the overarching regime or the disputing parties'.

${ }^{23}$ See, for example, the contributions in F Fontanelli, G Martinico, P Carrozza (eds), Shaping Rule of Law Through Dialogue: International and Supranational Experiences (Europa Law, Groningen, 2009); Slaughter, 'Typology' (n 11) 125-29; Helfer and Slaughter (n 14) 282; see also A Nollkaemper, National Courts and the International Rule of Law (Oxford University Press, Oxford, 2011) 299-304 who states at 301, 'The rule of law at the international and domestic levels is not a normative ideal or a requirement of separate legal orders, but is intimately connected and mutually reinforcing'; see also A Follesdal, 'International Human Rights Courts and the (International) Rule of Law: Part of the Solution, Part of the Problem, or Both?' (in this issue); G Palombella, 'Non-Arbitrariness, Rule of Law and the "Margin of Appreciation": Comments on Andreas Follesdal' (in this issue).

${ }^{24}$ Slaughter, 'Typology' (n 11) 121-2; see also EU Petersmann, 'Judging Judges: from "Principal-Agent Theory" to "Constitutional Justice" in Multilevel "Judicial Governance" of Economic Cooperation Among Citizens' (2008) 11 Journal of International Economic Law 827; EU Petersmann, 'Competing "Principles of Justice" in Multilevel Commercial, Trade and Investment Adjudication: Need for More "Judicial Dialogues" and Legal "Cross-Fertilization"” (2013) The Global Community Yearbook of International Law and Jurisprudence, vol. I 163; Benvenisti and Downs, 'Transjudicial Coordination' (n 20); C Marsan Raventós, 'From Judicial Dialogue to 
Finally, international courts engage in the progressive development of legal regimes and exercise governance functions. This has brought the question of their legitimacy to the forefront of recent scholarly debate. ${ }^{25}$ Different criteria are discussed as contributing to the legitimacy of courts. These include their internal set-up (e.g. the appointment procedure and the composition of the Bench regarding expertise, regional and gender representation), the decision-making procedure (e.g. deliberation and voting procedures), the foundational mandate (e.g. a constitution, treaty regime, UN Security Council resolution or executive act) and the wider social role and significance of the institution (e.g. peaceful dispute resolution, promotion of the rule of law, guardian of fundamental rights).

Yet the legitimacy of the judiciary depends not only on internal parameters of the institutional set-up or on procedure, but on a court's embedment in an institutional system of separation of powers. Domestic law usually specifies the competences and hierarchy of courts, the procedural requirements for initiating judicial proceedings, the legal effects of judgments, the different stages of appeal and the competences between parliaments and courts. As explained in the following two sections, political theorists and sociologists have long included in this system civil society and public spheres, which can provide accountability and legitimacy through a critical public discourse. ${ }^{26}$ Supranational courts lack a

Cosmopolitan Norms' in A Müller and HE Kjos (eds), Judicial Dialogue and Human Rights (Cambridge University Press, Cambridge, 2017) 435.

${ }^{25}$ For the burgeoning literature on the exercise of 'public authority' by international courts and other actors, see A v Bogdandy, P Dann and M Goldmann, 'Developing the Publicness of Public International Law: Towards a Legal Framework for Global Governance Activities' (2008) 9 German Law Journal 1375; A v Bogdandy and I Venzke, 'Zur Herrschaft internationaler Gerichte: Eine Untersuchung internationaler öffentlicher Gewalt und ihrer demokratischen Rechtfertigung' (2010) 70 Zeitschrift für ausländisches öffentliches Recht und Völkerrecht 1, especially 16-20; A v Bogdandy and I Venzke, 'On Democratic Legitimation of International Judicial Lawmaking' (2011) 12 German Law Journal 1341; A v Bogdandy and I Venzke, 'On the Functions of International Courts: An Appraisal in Light of Their Burgeoning Public Authority' (2013) 26 Leiden Journal of International Law 49; A v Bogdandy and I Venzke, In wessen Namen? International Gerichte in Zeiten globalen Regierens (Suhrkamp, Berlin, 2014); see also F Zarbiyev, 'Judicial Activism in International Law - A Conceptual Framework of Analysis' (2012) 3 Journal of International Dispute Settlement 1; M Dawson, 'The Political Face of Judicial Activism: Europe's Law-Politics Imbalance' in M Dawson, B de Witte and E Muir (eds), Judicial Activism at the European Court of Justice (Edward Elgar, Cheltenham, 2013) 11; Alter (n 9); N Grossman, H Grant Cohen, A Follesdal and Geir Ulfstein (eds), Legitimacy and International Courts (Cambridge University Press, Cambridge, 2018).

${ }^{26} \mathrm{~J}$ Habermas, The Structural Transformation of the Public Sphere: An Inquiry into a Category of Bourgeois Society (Polity Press, Cambridge, MA, 1989, original published in German in 1962); Fraser (n 6). 
comparable constitutional embedment but increasingly exercise a strong 'public authority'. ${ }^{27}$

It is against this background that judicial dialogue is posited as contributing to the perception of legitimacy of courts. The dialogue can provide a seal of transnational approval by embedding a judicial decision in a shared opinion or a transnational consensus of courts. Judicial decision-making is placed in a transnational justificatory discourse, which will increase its legitimacy and thus also improve compliance with the courts' decisions. ${ }^{28}$ Especially when courts engage in the progressive development of law, an alleged consensus can help to legitimize this law-developing activity. If successful, this may increase not only the legitimacy of judicial decisions, but also of the judicial praxis to engage in this type of progressive development of the law. ${ }^{29}$

In summary, this section briefly restated how dialogue between courts connotes particular ideals of communities and networks with 'common' interests, purposes and opinions. The dialogue within judicial communities will ideally lead to a consensus and enhance the legitimacy, authority and effectiveness of judicial decisions. Ultimately, this can lead to the belief that judicial networks can legitimately exercise governance tasks more effectively than (allegedly) disaggregated national political institutions and fragmented publics. In the next section, I critique this vision of judicial dialogue by highlighting inherent conditionalities, inequalities and subtle processes of homogenization and socialization that affect such dialogues. As I explained, I rely on the idea and critique of the formation of common opinions in an idealized public sphere as developed by Jürgen Habermas and other scholars. The bourgeois ideal of a public discursive space has been criticized, including by Habermas himself, for overlooking important biases in the opinion-forming process.

\section{The transnational judicial public sphere as an idea and ideology}

In The Structural Transformation of the Public Sphere, Jürgen Habermas describes the emergence and transformation of the bourgeois public sphere in

27 See G Ulfstein, 'Transnational Constitutional Aspects of the European Court of Human Rights' (in this issue); W Sadurski, 'Quasi-Constitutional Court of Human Rights for Europe? Comments on Geir Ulfstein' (in this issue).

28 See Helfer and Slaughter (n 14) 282-7, who write at 282: 'By communicating with one another in a form of collective deliberation about common legal questions, these tribunals can reinforce each other's legitimacy and independence from political interference. They can also promote a global conception of the rule of law, acknowledging its multiple historically and culturally contingent manifestations but affirming a core of common meaning'.

29 See Waldron (n 7) and Tamanaha (n 7) (in this issue). 
the national contexts of Germany, France and Great Britain. ${ }^{30}$ In Habermas's appraisal, the societal exchange creates a public sphere (Öffentlichkeit) as a separate realm between the private and the political sphere. ${ }^{31}$

According to its idealized conception, the principal functions of the public sphere are 'the detection, identification, and interpretation of problems affecting society as a whole'. ${ }^{32}$ In this sphere, the (allegedly) open and inclusive discourse can enable the communicative generation of critical public opinion about common concerns (normative legitimacy of public opinion). ${ }^{33}$ In addition, public opinion will inform political and legal institutions and hold them accountable. Its purpose is to discredit policies and laws that 'cannot withstand critical scrutiny or to assure the legitimacy of those that do' (political efficacy of public opinion). ${ }^{34}$ Habermas also describes the structural transformation of the public sphere due to the influence of economic interests and mass media. He stresses the democratic importance of public discourse, but also criticizes this idealized notion of the public sphere for overlooking conditionalities and systemic obstacles that affect the open discourse and its critical function. At least to some extent,

${ }^{30}$ Habermas (n 26); for an insightful synopsis, see C Calhoun, 'Introduction: Habermas and the Public Sphere' in Calhoun (n 6) 1, 4-29.

${ }^{31}$ Habermas (n 26) 27-31; J Habermas, Between Facts and Norms: Contributions to a Discourse Theory of Law and Democracy (MIT Press, Cambridge, MA, 1996) 373; see also C Taylor, 'Invoking Civil Society' (n 5) 217.

32 J Habermas, 'Three Normative Models of Democracy' in C Cronin and P De Greiff (eds), The Inclusion of the Other (MIT Press, Cambridge, MA, 1998) 251; in Between Facts and Norms (n 31) 359 he describes the purposes of the public sphere as 'a sounding board for problems that must be processed by the political system because they cannot be solved elsewhere. To this extent, the public sphere is a warning system with sensors that, though unspecialized, are sensitive throughout society. From the perspective of democratic theory, the public sphere must, in addition, amplify the pressure of problems, that is, not only detect and identify problems but also convincingly and influentially thematize them, furnish them with possible solutions, and dramatize them in such a way that they are taken up and dealt with by parliamentary complexes. Besides the "signal" function, there must be an effective problematization' (emphasis in the original); at 365: 'its function of perceiving and thematizing encompassing social problems' and at 381: 'detecting and identifying new problem situations'.

${ }^{33}$ Habermas, Structural Transformation (n 26) 36, 83, 89 et seq and 236-50; Habermas, Between Facts and Norms (n 31) 359 et seq; Kate Nash writes: 'The ideal of the public sphere, if it is invariably concretized in exclusionary ways, always also gestures beyond itself, to ideals of genuine participation in establishing the common good': see K Nash, 'Introduction' in K Nash (ed), Transnationalizing the Public Sphere: Nancy Fraser et al. (Polity Press, Cambridge, MA, 2014) 1.

${ }^{34}$ N Fraser, 'Transnationalizing the Public Sphere: On the Legitimacy and Efficacy of Public Opinion in a Post-Westphalian World' in N Fraser, Scales of Justice: Reimagining Political Space in a Globalized World (Polity Press, Cambridge, MA, 2008) 76-77, where she identifies these two conditions - the normative legitimacy and political efficacy of public opinion - as 'essential to the concept of the public sphere in critical theory'; see also ibid. 80-81. 
these systemic obstacles prevent it from becoming a forum for developing legitimate common opinions. This is the critique on which I rely here.

The notion of the public sphere and its assumptions were later further refined and criticized. ${ }^{35}$ Scholars questioned, for example, the legitimacy of public discourses and alerted us to the exclusionary nature of the bourgeois public sphere, whose openness and egalitarian ideal were undermined by the importance of social class, education and status. Critics pointed out that the democratic and legitimizing qualities of public rational discourses depended also on the existence and admission of subaltern counter-publics. ${ }^{36}$ In other words, they showed that 'the' public sphere consisted of numerous different publics with varying opportunities of influence. This included the distinction between strong publics with decisional powers, such as parliaments, and weaker publics seeking to increase their influence. ${ }^{37}$

The notion of the public sphere resonated also with scholarship on the reconstruction of the concept of civil society in the context of the reform movements in Eastern Europe at the end of the last century. ${ }^{38}$ The emerging scholarship after the Cold War used the concept of civil society to analyze social organization in movements and the interrelations between political, economic and civil actors. Through a normative and political assessment of the early Habermasian concept of the public sphere, scholars analyzed the logics of influence in wider civil society. This included not only the effects of

35 See J Habermas, Legitimation Crisis (Beacon Press, Boston, 1975); for early critiques of Habermas, see J Cohen, 'Why more Political Theory?' (1979) 40 Telos: A Quarterly Journal on Radical Thought 70, who emphasized democratizing functions and traditions in the public sphere despite its 'transformation' due to the influence of capitalist consumerism, the bureaucratization of political parties or the transformation of a critical press; O Negt and A Kluge, Public Sphere and Experience: Toward an Analysis of the Bourgeois and Proletarian Public Sphere (University of Minnesota Press, Minneapolis, MN, 1993, originally published in German in 1972) who criticized the bourgeois public sphere as representing dominant structures of society and stressed the importance of counter-publics, different degrees of publicity and inequality of constituencies; $\mathrm{N}$ Luhmann, Political Theory in the Welfare State (Walter de Gruyter, Berlin, 1990, originally published in German in 1981) 203-27, who questioned in Chapter VII the reduction of complexity that a notion of 'public opinion' presupposes; he tried to reconstruct this notion in light of the intricate temporal and material assumptions of public opinion.

${ }^{36}$ On the feminist critique of the distinction between the public and the private and the fundamental relevance of counter-publics, see S Benhabib, 'Models of Public Space: Hannah Arendt, the Liberal Tradition, and Jürgen Habermas' in Calhoun (n 6) 73, 89 et seq.; Fraser (n 6); JB Landes, 'The Public and the Private Sphere: A Feminist Reconsideration' in J Meehan (ed), Feminists Read Habermas: Gendering the Subject of Discourse (Routledge, New York, 1995) 91-116.

37 See (n 6); see also Fraser (n 34) 81-82.

38 See Cohen and Arato (n 6); AB Seligman, The Idea of Civil Society (Princeton University Press, Princeton, NJ, 1992); K Kumar, 'Civil Society: An Inquiry into the Usefulness of an Historical Term' (1993) 44 The British Journal of Sociology 375; JR Ehrenberg, Civil Society: The Critical History of an Idea (2nd edn, New York University Press, New York, 2017). 
increased institutionalization and the influence of economy elites, but also other systemic obstacles that interest us here. ${ }^{39}$

Although the two notions of public sphere and civil society share similar features, they are not identical. ${ }^{40}$ The public sphere is a part of civil society and has a strong emphasis on rational-critical discourse, opinion formation and the potential to influence political power through public accountability.

In what follows, I use arguments from these debates to describe conditionalities and systemic obstacles that can taint the assumption that judicial dialogue produces legitimate common opinions and common interests of judges. There is the risk that judicial dialogue is construed as a tool to promote an alternative and complementary discursive sphere that conflates transnational judicial governance and its legitimization. As Habermas aptly observes regarding public discourses, 'Of course, actual influence coincides with legitimate influence just as little as the belief in legitimacy coincides with legitimacy. ${ }^{41}$

\section{Social standing and openness}

Just as debates about the public sphere have emphasized differences in status of participants, courts, too, differ in status and influence. Judicial dialogue, like dialogue between citizens in an idealized public sphere, builds on presumptions of an open, inclusive, equal, voluntary and unconstrained discourse between judges. In social practice, however, the influence of the US or South African Supreme Court, the German Bundesverfassungsgericht or the French Conseil constitutionnel is far from comparable to the influence of the supreme court of, for example, Cyprus. Decisions and opinions of courts that are widely viewed as successful and influential are naturally more likely to exert influence. Participation in a judicial dialogue may in principle be open, but effectively depends on status, means and influence. ${ }^{42}$ While every court may intend to make its voice heard, the likeliness to be heard and the weight given to the voice differ. Apart from social standing and recognition,

39 On a reconstruction of civil society that tries to avoid a 'colonization' of the concept by the state or the economy (bureaucratization and monetization), see A Arato and J Cohen, 'Civil Society and Social Theory' (1998) Thesis Eleven 21, 40; more extensively, see A Arato and J Cohen, Civil Society and Political Theory (n 6) 420 et seq.

40 See C Calhoun, 'Civil Society and the Public Sphere' (1993) 5 Public Culture 267.

${ }^{41}$ Habermas, Between Facts and Norms (n 31) 362-63.

42 See also Fraser (n 6) 118 et seq; Landes (n 36) 97 et seq on how deliberation can mask domination and how social inequalities persist in deliberation even in the absence of any formal exclusions; for the public sphere, see Habermas, Structural Transformation (n 26) 85 acknowledging that participation in the bourgeois public sphere was primarily conditioned on economic means and education and Between Facts and Norms (n 31) 363-4 and 374-5 for a differentiation between actors who actually appear actively in public discourses and spectators; see also J Habermas, 'Further Reflections on the Public Sphere', in Calhoun (n 6) 422 et seq. 
material means also influence whether a court is financially and logistically equipped to translate its judgements into English and make them widely available. ${ }^{43}$ Moreover, if a court is in a position to convene regular meetings with judges from other jurisdictions, as the Bundesverfassungsgericht and other apex courts do, this might not simply be a sign of dedication to exchange and mutual learning through dialogue; it also ensures that the court's own voice is more widely heard. ${ }^{44}$ This 'exchange' is also a means to disseminate the judges' own opinions and to build transnational alliances.

Within this 'dialogue', a court might not even know whether and when another court cites its decision, especially if the decisions are not translated. Noticeable and traceable judicial exchanges in the transnational judicial public sphere are, therefore, effectively reduced to a few well-known international and regional, and a small number of domestic, supreme courts with the International Court of Justice, the Court of Justice of the European Union, the European Court of Human Rights, the WTO Appellate Body and some predominantly Western European and North American constitutional courts inhabiting the most prominent positions. ${ }^{45}$ In most cases, the engagement with the decisions of these courts seems to stem from a social or institutional hierarchy and not necessarily from an interest in mutual dialogue. The dialogue may foster this hierarchy instead of challenging it.

\section{Commonalities and socialization}

In this environment of unequal influence, it becomes harder for less prominent participants to deviate from the mainstream opinion. If judicial dialogue is conceptualized as a means to create a transnational consensus and common purposes for courts, then this can involve strong biases of the profession. Within a professional community, certain opinions and arguments might be frowned upon while other positions bring acknowledgement and esteem. Social pressures within a professional group make it increasingly unlikely that alternative arguments or solutions will gain force. ${ }^{46}$ Hence, being part of a dialogue does not mean a mere exchange of technical knowledge but also entails the exposure to socialization dynamics. ${ }^{47}$

43 See the valuable project on 'International Law in Domestic Courts' at Oxford University Press which provides translations of selected national judgments; on further institutional and resource constraints that can affect judicial dialogue, see DS Law, 'Judicial Comparativism and Judicial Diplomacy' (2015) 163 University of Pennsylvania Law Review 927, 1009-20.

${ }^{44}$ Law, ibid. 1000, 1007 and 1009.

45 The volume edited by Müller/Kjos (n 24) contains three contributions that break with this pattern.

46 M Finnemore and K Sikkink, 'International Norm Dynamics and Political Change' (1998)

52 International Organization 887, 905 and 912.

47 Ibid 905; Slaughter (n 10) 198-203. 
Dialogues within professional communities set standards of appropriateness for their members, ${ }^{48}$ and which standard prevails depends largely on the influence of dominant members and hence on engrained social power structures. ${ }^{49}$ Together with other factors, this influences which judicial opinions and decisions will most likely succeed in the 'dialogue'.

The social environment thus exerts strong pulls towards the perceived center, with strong incentives to conform. As I have mentioned before, the analysis of judicial networks of human rights courts has employed for a very long time an almost exclusive focus on a few international courts and on (Western) European and North American liberal constitutional states with a functioning judiciary. ${ }^{50}$ Some scholars describe these mainstreaming effects of 'dialogue' and the related pull towards the center as the building and securing of hegemonic influence. ${ }^{51}$

The socialization processes manifest precisely in the postulation of common purposes, the alleged existence of a 'consensus' and the idea of a shared professional culture. These references to common interests and purposes claim to 'identify' the community-wide validity of a particular idea, value or interest. ${ }^{52}$ Yet they also express an interest in universalizing this idea, value or interest in the first place. ${ }^{53}$

48 See PM Haas, 'Do Regimes Matter? Epistemic Communities and Mediterranean Pollution Control' (1989) 43 International Organization 377; MN Barnett and M Finnemore, 'The Politics, Power, and Pathologies of International Organizations' (1999) 53 International Organization 699; Toufayan (n 15) 329 et seq.

49 Toufayan (n 15) 325 describes how the distinction between 'effective' and 'ineffective' human rights protection mechanisms inside and outside Europe is part of a 'civilizing mission of [the] transjudicialism theorists' project and these regional systems' conceptual self-understanding and identity-building'.

${ }^{50}$ Slaughter's liberal theory of transnational judicial networks is often criticized for its Eurocentric focus: see, for example, Toufayan (n 15) 319 et seq and 323-24, where he writes that, 'Liberal theorists harbor stronger intellectual affinities with the European Court of Justice (ECJ) and ECtHR's modes of judicial reasoning and interpretative methodologies which they consider superior. The claim to "newness" of the rise of a global community of law beyond Europe through judicial dialogue accordingly rests on a familiar form of colonialist and imperialist narrative. "Dialogue" ideology has shaped the very modes of professional discourse and debate about legal pluralism from the time of their origins - for, as some commentators have recorded, phenomena of cross-fertilization and transplanted plural legal orders were pervasive among the courts of imperial powers and their colonies'.

51 Ibid. 325; N Krisch, 'International Law in Times of Hegemony: Unequal Power and the Shaping of the International Legal Order' (2005) 16 European Journal of International Law 369.

52 Slaughter (n 10) 198-203.

53 Fraser (n 6) 128-32; Calhoun (n 30) 35; see also Mills and Stephens (n 19) 18, 20-3. Regarding the representation of particular interests of a selected group of participants as expressions of a common interest or a common good, see Habermas, Structural Transformation (n 26) 87. 
Similar to the public sphere at the domestic level, transnational judicial dialogues cannot dispense with domination. ${ }^{54}$ As the fragmentation debate in international law has shown, behind concerns about systemic coherence and unity lie not only normative but institutional conflicts and rivalries. These institutional interests affect the dialogues and result in a heterogeneous quest for 'systemic integration'. An inter-institutional dialogue always also entails struggles about influence and authority.

\section{Paradigms and pragmatism}

Friedrich Kratochwil has reminded us that the rule of law has developed from a political notion empowering free citizens as the authors of law to a construct empowering legal professionals who administer the legal order. ${ }^{55}$ What Kratochwil sharply observes behind the shifting meaning and function of the rule of law is an empowerment of those who determine its meaning. I agree that these 'shifts' - or, rather, additional layers - of the meanings, functions and purposes of our conceptions have far-reaching consequences. If judicial dialogue is understood as a new paradigm of judicial cooperation, this not only shifts the meaning of judicial reasoning, but has also effects on the 'judicial function'. This changing function becomes problematic when judges substitute or compensate for other democratic institutions and processes. Thus judicial dialogue may lead us to think of courts instead of other actors and processes.

A final qualification relates to the idea of dialogue itself. Cross-references between courts do not necessarily take the form of a dialogue understood as a mutual exchange. ${ }^{56} \mathrm{~A}$ court's opinion needs to be cited and interpreted by others in order to exert influence in a dialogue. As in all discourses, the reception of a court's voice, and the weight and meaning given to it, depend on selective and interpretative processes by other courts. We hardly know which judgments and decisions are overlooked or remain unmentioned in judicial reasoning. Hence, the selection and interpretation of foreign jurisprudence by a court might be less motivated by an interest in contributing to

${ }^{54}$ Habermas, Structural Transformation (n 26) 122; Kratochwil (n 19) 135.

55 F Kratochwil, 'Has the "Rule of Law" become a "Rule of Lawyers"? An Inquiry into the Use and Abuse of an Ancient Topos in Contemporary Debates' in G Palombella and N Walker (eds), Relocating the Rule of Law (Hart, Oxford, 2009) 185.

56 DS Law and WC Chang, 'The Limits of Global Judicial Dialogue' (2011) 86 Washington Law Review 523, 534 and passim; see further M Gelter and M Siems, 'Networks, Dialogue or One-Way Traffic? An Empirical Analysis of Cross-Citations Between Ten of Europe's Highest Courts' (2012) 8 Utrecht Law Review 88; L Pasquet, 'Dialogue or Interaction? A NonCosmopolitan Reading of Transjudicial Communication' in Müller and Kjos (n 24) 467. 
a transnational judicial dialogue than in finding strategic support for a preferred argumentation in a particular case. The decision about whether or not to engage in dialogue with other courts, how the opinions of other courts are weighted and what meaning these opinions receive can, therefore, be less a matter of commitment to a common purpose than of strategic choice and pragmatic interest.

I emphasized in this section that judicial dialogue entails inequalities, universalizing processes, socialization dynamics and pragmatic interests. This in turn conditions the functions and the meanings of judicial dialogue. It questions its effectiveness and legitimizing potential. Increasingly, judges find themselves placed (and, on occasion, place themselves) within universal ambitions that go far beyond the adjudication of a concrete case. ${ }^{57}$ Only if a reference to a foreign court is construed as a dialogue, ${ }^{58}$ with particular meanings and purposes, does judicial dialogue become an expression of collective action. ${ }^{59}$ Judges become agents of allegedly 'common' interests and shall ensure the progress, unity, consistency and legitimacy of a transnational legal order. Their voice is taken out of the context of concrete decision-making in the case at hand and relocated into the realm of a transnational community, a network or into humanity. In the next section, I discuss how a theoretical understanding of judicial dialogue that acknowledges these inherent conditionalities and contingencies could guide more critical research on judicial dialogue and judicial legitimacy.

\section{Judicial dialogue and the transnational challenge}

It remains one of the most difficult challenges for governance and democratic theory to accommodate the fact that an ever-growing range of actors escape traditional roles in transnational governance activities. This is also true for courts. On occasion, judges do engage in 'law-making', participate as partisans in public discourses and set policy goals. It would be a mistake to believe that courts do this only to fill 'gaps' and to compensate for the powers lost by allegedly disaggregated states. Judges may, in fact, actively seek to enlarge their own authority. ${ }^{60}$

A more critical understanding of judicial dialogues can provide a refined awareness of how and why these dialogues influence judicial decisionmaking, how they are contingent on and reflect social power structures

57 Mills and Stephens (n 19) 19.

${ }^{58}$ For a very wide conception of 'dialogue', see A Müller and HE Kjos, 'Introduction' in Müller/Kjos (n 24) 1, 12-5.

59 See Law and Chang (n 56).

${ }^{60}$ See Waldron (n 7) and Tamanaha (n 7). 
and how international, regional and domestic dialogical spheres interact. ${ }^{61}$ Such an approach places judicial dialogue in the social contexts of institutionalization processes, functional cooperation and professional mainstreaming. It also helps to critically question the construction and legitimization of new forms of public authority.

It is a fundamental cornerstone of Habermas's theory of deliberative politics that 'discourses do not govern'. ${ }^{62}$ Opinions formed in the public sphere need to gain communicative power, and for this they require transformation through an institutionalized political process. As Habermas observes:

In fact, the interplay of a public sphere based in civil society with the opinion- and will-formation institutionalized in parliamentary bodies and courts offers a good starting point for translating the concept of deliberative politics into sociological terms ... within the boundaries of the public sphere, or at least of a liberal public sphere, actors can acquire only influence, not political power. The influence of a public opinion generated more or less discursively in open controversies is certainly an empirical variable that can make a difference. But public influence is transformed into communicative power only after it passes through the filters of the institutionalized procedures of democratic opinion- and will-formation and enters through parliamentary debates into legitimate lawmaking. The informal flow of public opinion issues in beliefs that have been tested from the standpoint of the generalizability of interests. Not influence per se, but influence transformed into communicative power legitimates political decisions. The popular sovereignty set communicatively aflow cannot make itself felt solely in the influence of informal public discourses - not even when these discourses arise from autonomous public spheres.

${ }^{61}$ For a differentiated approach to judicial interactions, see A Nollkaemper, 'Conversations Among Courts: Domestic and International Adjudicators' in CPR Romano, KJ Alter and Y Shany (eds), The Oxford Handbook of International Adjudication (Oxford University Press, Oxford, 2014) 523.

${ }^{62}$ Habermas, 'Further Reflections' (n 42) 452: 'The responsibility for practically consequential decisions must be based in an institution. Discourses do not govern. They generate a communicative power that cannot take the place of administration but can only influence it. This influence is limited to the procurement and withdrawal of legitimation. Communicative power cannot supply a substitute for the systematic inner logic of public bureaucracies'; see also Habermas, Between Facts and Norms (n 31) 359: 'The capacity of the public sphere to solve problems on its own is limited. But this capacity must be utilized to oversee the further treatment of problems that takes place inside the political system' (emphasis in the original); and 362: 'To this extent, the communication structures of the public sphere relieve the public of the burden of decision making; the postponed decisions are reserved for the institutionalized political process' (emphasis in the original); for further discussion of how 'institutionalized deliberations in parliamentary bodies' and 'informal networks of the public sphere' interrelate in deliberative politics, see Habermas, 'Three Normative Models' (n 32) 247-49. 
To generate political power, their influence must have an effect on the democratically regulated deliberations of democratically elected assemblies and assume an authorized form in formal decisions. This also holds, mutatis mutandis, for courts that decide politically relevant cases. ${ }^{63}$

In particular, the last sentence of this quote deserves our attention. Throughout his work, Habermas stresses parliamentary debates and institutional law-making as indispensable filters to transform public opinion into legitimate political decisions. It is, therefore, not surprising that in his contributions on European and international law, Habermas does not primarily focus on courts but on the development of political and representative organs and on civil society actors. ${ }^{64}$

Professor Nancy Fraser is one of the scholars to have put forward challenging questions about how a critical theory of a transnationalized public sphere could be developed. ${ }^{65}$ Such transnational spheres are necessary to hold transnational authorities accountable. Fraser asks how we can reconceptualize the 'who' of public deliberation (dispersed interlocutors of global discourses in addition to national citizenry), the 'what' (transnational in addition to national public opinions and common interests), the 'where' (the global, 'glocal' and the cyperspace in addition to the nation-state), the 'how' (social media and new technologies in addition to traditional media) and the 'to whom' (private, public and semi-public transnational powers in addition to state institutions) in order to meaningfully interrogate the legitimacy and efficacy of public opinion. ${ }^{66}$ She proposes to reconceptualize both the group of interlocutors, who can form legitimate public opinions, and the possible addressees of public opinion, who are able to translate public opinion into administrative power. She writes:

${ }^{63}$ Habermas, Between Facts and Norms (n 31) 371-72 (emphasis in original).

${ }^{64} \mathrm{~J}$ Habermas, 'The Postnational Constellation and the Future of Democracy' in M Pensky (ed), The Postnational Constellation (MIT Press, Cambridge, MA, 2001) 58, 110-11; J Habermas, 'A Political Constitution for the Pluralist World Society?' in Habermas (n 1) 312, 342-52; J Habermas, 'The Constitutionalization of International Law and the Legitimation Problems of a Constitution for World Society' in J Habermas (ed), Europe: The Faltering Project (Polity Press, Cambridge, 2009) 109, 118-23; however, Bogdandy and Venzke, 'Zur Herrschaft internationaler Gerichte' (n 25) 5 characterize the demure treatment of courts in Habermas's work on international law as surprising (verwunderlich), astonishing (erstaunlich) and as a void (Leerstelle).

${ }^{65}$ Fraser (n 34); see also Nash (n 33); for the European context, see H Wessler, B Peters, M Brüggemann, K Kleinen-von Königslöw, S Sifft, Transnationalization of Public Spheres (Palgrave Macmillan, New York, 2008); B Peters, S Sifft, A Wimmel, M Brüggemann, K Kleinen-von Königslöw, 'National and Transnational Public Spheres: The Case of the EU' (2005) 13 European Review 139.

${ }^{66}$ Fraser (n 34) 98. 
[A critical conception of public-sphere theory] must consider the need to construct new addressees for public opinion, in the sense of new, transnational public powers that possess the administrative capacity to solve transnational problems. The challenge, accordingly, is twofold: on the one hand, to create new, transnational public powers; on the other, to make them accountable to new, transnational public spheres. Both those elements are necessary; neither alone is sufficient. Only if it thematizes both conditions (capacity as well as translation) will public-sphere theory develop a post-Westphalian conception of communicative efficacy that is genuinely critical. ${ }^{67}$

It is here that the reconstruction of the concepts of civil society and the public sphere gains renewed relevance. Legal and governance scholars tend to focus on the exercise of various forms of authority, but downplay inherent systemic conditionalities and often overlook the fundamental role of critical public spheres. On the other hand, scholarship on (transnational) public spheres focus on civil society, parliaments and the economy but neglect the role of courts as strong, decisional publics. Andrew Arato, Jean Cohen and other scholars emphasize the need for mutual understanding and agreement on intersubjectively recognized norms that involve also communicative processes of learning, integration and socialization. This in turn requires a juridification in order to stabilize these processes, and it also requires mediating institutions that can translate the influence of civil society and public opinions into political power. ${ }^{68}$

It is worth thinking further about the question of the role played by courts as transnational public actors without converting them into principal governance agents. Courts can stabilize or destabilize this juridification by either strengthening or weakening decisional and informal publics. More importantly, courts have strong decisional powers without belonging to the 'political society' of parliaments and parties. Courts thus require both formal and informal democratic oversight beyond the nation-state.

If we follow this deliberative liberal idea of democracy and public discourse, then courts too are addressees for public opinion and may function as 'filters' and 'mediating institutions' that can transform public opinion into politically effective communicative power. Also, through courts civil society 'can gain influence over political/administrative and economic processes'. ${ }^{69}$

${ }^{67}$ Ibid, 86-87 and 92 .

68 Arato and Cohen, 'Civil Society and Social Theory' (n 39) 42; see also J Cohen, 'Interpreting the Notion of Civil Society' in M Walzer (ed), Toward a Global Civil Society (Berghahn Books, Oxford, 1995) 35, 38.

${ }^{69}$ Cohen, ibid; see also A Arato, 'Populism, Constitutional Courts, and Civil Society' in C Landfried (ed), Judicial Power: How Constitutional Courts Affect Political Transformations (Cambridge University Press, Cambridge, 2019) 318. 
In addition, courts can help to create transnational publics, empower counterpublics, foster interaction between different types of publics and mediate between them. In fact, the judicial strengthening of transnational publics that are in turn able to hold also courts accountable would be a crucial contribution of courts to the legitimacy of their own public authority.

However, as I have argued, courts cannot substitute for these public discourses in civil society or parliaments. They do not merely detect, identify and interpret problems affecting society as a whole in an open-ended way; they deliver authoritative decisions. ${ }^{70}$ The public sphere, the rule of law and the legitimate exercise of authority cannot be transplanted, complemented or substituted at will, not even on different 'multi-levels' or within a selfreferential network of a transnational judiciary. ${ }^{71}$

This understanding recognizes the discussed inequalities and systemic obstacles. There is no empty zone that is free of influence and inequalities. ${ }^{72}$ This is why the plurality of public spheres is so essential for the legitimacy of public opinions. ${ }^{73}$ This means that judicial dialogues need to recognize and protect diversity and pluralistic contestations within themselves beyond a 'common opinion'. Especially in the international context, where there is no global institutionalized strong decisional public and no stable framework equivalent to the nation state, the interaction of judicial dialogical spheres to other local and transnational publics - strong and weak, as well as formal and informal - is essential to avoid a juristocracy. ${ }^{74}$

${ }^{70}$ Habermas, 'A Political Constitution' (n 64) 349; Kratochwil (n 19) 141; Taylor (n 4) 282 85 warns that an increasing 'politics-as-judicial-review' may be a sign for political disempowerment and exclusion of other actors and institutions.

${ }^{71}$ Habermas, Between Facts and Norms (n 31) 364: 'a public sphere cannot be "manufactured" as one pleases. Before it can be captured by actors with strategic intent, the public sphere together with its public must have developed as a structure that stands on its own and reproduces itself out of itself' (emphasis in original); see also Kratochwil (n 19) 126-27, who writes that, 'For a "liberal" theory it is then in a way rather surprising that all politics seems to have disappeared, at least at first sight. Thus, "politics," conceived as the agreement among free members of a society, has been overshadowed, if not replaced, by a form of third-party authoritative decision-making "bound" by law.'

${ }^{72} \mathrm{~N}$ Onuf, 'Late Modern Civil Society' in RD Germain and M Kenny (eds), The Idea of Global Civil Society: Politics and Ethics in a Globalizing Era (Routledge, London, 2005) 47.

${ }^{73}$ On the crucial importance of plurality and diversity, see Fraser (n 6) 116, 121-28 and 13236; Taylor (n 4) 280, who speaks of 'a multiplicity of public spheres nested within each other'; M Walzer, 'The Concept of Civil Society' in Walzer (n 68) 7, 25-27; G Eley, 'Nations, Publics, and Political Cultures: Placing Habermas in the Nineteenth Century', in Calhoun (n 6) 289; see further Habermas, 'Further Reflections' (n 42) 424-5 and Habermas, Between Facts and Norms (n 31) 373-4; Calhoun (n 40) 272-73 and 279; N Couldry, 'What and Where is the Transnationalized Public Sphere?' in Nash (n 33) 43, 45 and passim, who conceives of the transitional public sphere 'not as a single thing, but as the networked resultant of transformations at multiple levels'.

${ }^{74}$ See also A Arato, 'The Rise, Decline and Reconstruction of the Concept of Civil Society, and Directions for Future Research' (1994) 1 The Public 45, 49. 
Thus for our understanding of the public authority and legitimacy of courts, a deeper insight into the relation of courts to various publics and their legitimizing potential is essential. This is not only a question for empirical research; it also requires theoretical analysis and foundation. The discussion here has only been a first step towards these further inquiries into the potential and limits of judicial dialogues and wider interactions in light of critical democratic theory.

\section{Conclusions}

Dialogue is not panacea. Dialogue is always more than a neutral, openended process. In the foregoing discussion, I have not argued against the idea of judicial dialogue. I wanted to raise awareness of the wider functions and meanings of judicial dialogue and the inherent systemic obstacles that can taint the legitimacy and effectiveness of these dialogues.

Further critical research is needed on the nature and role of judicial dialogues in judicial governance in order to assess how courts influence transnational normative processes and how they can contribute to the strengthening of multiple transnational public spheres. In this research, we should not simply look for alternative fora and categories of authority that 'simply' require alternative forms of legitimization. Ultimately, the promise of judicial dialogue lies less in creating commonalities between courts and legitimizing their authority, than in bringing alternatives and a plurality of opinions to the fore.

\section{Acknowledgements}

The author wishes to thank Gráinne de Búrca, Andreas Føllesdal, Friedrich Kratochwil and especially the two anonymous reviewers who read earlier versions of this article and provided excellent comments. I am also grateful for comments by Claudio Corradetti, Hege Elisabeth Kjos, Amrei Sophia Müller and other participants of a PluriCourts conference at the University of Oslo, where an early version of this article was first presented and discussed. The usual disclaimer applies. 